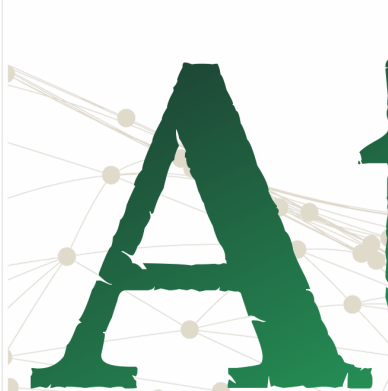

ISSN n² 2526-8031

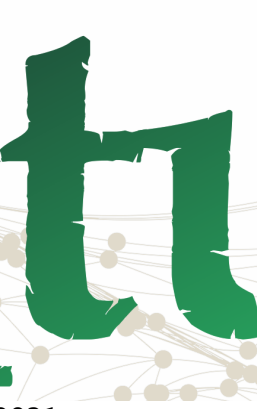

tur
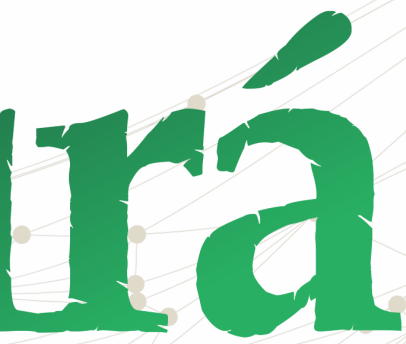

Pan-Amazônica de Comunicação

Vol. 3, n. 3, Setembro-Dezembro. 2019

\title{
O COMPORTAMENTO DA LINGUAGEM JORNALÍSTICA NAS STORIES DO INSTAGRAM: ESTUDO DOS PERFIS DO JORNAL O GLOBO E DO PORTAL A CRÍTICA
}

The Behavior of the Journalistic Language on Instagram Stories: A Study About Jornal O Globo and Portal A Crítica Profiles

El Comportamiento del linguaje periodístico em las historias de Instagram: Estudio de los perfiles de Jornal O Globo y Portal A Crítica

\section{Alessandra Augusto Taveira ${ }^{1}$ \\ Mirna Feitoza Pereira ${ }^{2,3}$}

\section{RESUMO}

A adesão dos consagrados veículos jornalísticos a recente proposta de comunicação das Stories do Instagram desvela variadas possibilidades de construção e disseminação da notícia neste ambiente, que ainda possui uma estrutura em vias de se estabelecer. A apropriação deste meio por veículos como Folha de S. Paulo, Nexo Jornal e Estadão denota que um caminho está sendo trilhado, mas deixando lacunas no tratamento dado à notícia. Neste sentido, o presente artigo tem por objetivo investigar o comportamento da linguagem jornalística nas Stories do Instagram dos perfis do Jornal O Globo e do Portal A Crítica a partir da identificação do processo de codificação da notícia neste ambiente, de

\footnotetext{
${ }^{1}$ Graduanda em Comunicação Social/habilitação Jornalismo na Faculdade de Informação e Comunicação da Universidade Federal do Amazonas (FIC/UFAM). Integrante do Grupo de Pesquisa em Semiótica da Comunicação -Mediação, e pesquisadora bolsista PIBIC/FAPEAM com o projeto "O Comportamento da Linguagem Jornalística nas Stories do Instagram: Estudo dos Perfis do Jornal O Globo e do Portal A Crítica". Email: alessandrataveiraa@gmail.com.

${ }^{2}$ Doutora em Comunicação e Semiótica pela Pontifícia Universidade Católica - SP. Professora na Faculdade de Informação e Comunicação da Universidade Federal do Amazonas (UFAM), onde ministra disciplinas relacionadas às teorias e práticas jornalísticas e às teorias e metodologias da pesquisa em comunicação. Líder do Grupo de Pesquisa em Semiótica da Comunicação - Mediação. E-mail: mirnafeitoza@gmail.com.

${ }^{3}$ Endereço de contato das autoras (por correspondência): Universidade Federal do Amazonas, Faculdade de Informação e Comunicação. Setor Norte do Campus, Av. General Rodrigo Octavio Jordão Ramos, 1200, Coroado I. CEP: 69067-005. Manaus, AM - Brasil.
} 


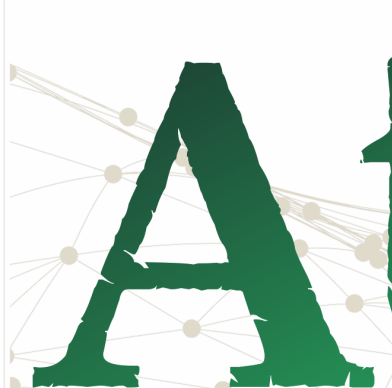

ISSN n² 2526-8031
Revista

Pan-Amazônica

de Comunicação

Vol. 3, n. 3, Setembro-Dezembro. 2019

modo a comparar as performances de ambos quanto à utilização do recurso em questão, a fim de refletir sobre as possibilidades da linguagem jornalística nas Stories. Para tanto, utilizou-se como metodologia a adoção do ponto de vista semiótico para os estudos da comunicação, conforme Machado (2001).

PALAVRAS-CHAVE: Linguagem Jornalística; Instagram; Stories; Jornal O Globo; Portal A Crítica.

\section{ABSTRACT}

The adhesion of the renowned journalistic vehicles to the recent communication proposal of Instagram Stories reveals various possibilities of construction and dissemination of news in this environment, which still has a structure in the process of being established. The appropriation of this medium by vehicles such as Folha de S. Paulo, Nexo Jornal and Estadão denotes that a path is being followed, but leaving gaps in the treatment given to the news. In this sense, this article aims to investigate the behavior of journalistic language in the Instagram Stories of the profiles of Jornal O Globo and Portal A Crítica from the identification of the news coding process in this environment, in order to compare the performances of both regarding the use of the resource in question, in order to reflect on the possibilities of journalistic language in the Stories. Therefore, the methodology adopted was the adoption of the semiotic point of view for communication studies, according to Machado (2001).

KEYWORDS: Journalistic Language; Instagram; Stories; Jornal O Globo; Portal A Crítica.

\section{RESUMEN}

La adhesión de los vehículos periodísticos de renombre a la reciente propuesta de comunicación de Instagram Stories revela varias posibilidades de construcción y difusión de noticias en este entorno, que todavía tiene una estructura en proceso de establecimiento. La apropiación de este medio por vehículos como Folha de S. Paulo, Nexo Jornal y Estadão denota que se está siguiendo un camino, pero que deja vacíos en el tratamiento dado a las noticias. En este sentido, este artículo tiene como objetivo investigar el comportamiento del lenguaje periodístico en las Historias de Instagram de los perfiles de Jornal O Globo y Portal A Crítica a partir de la identificación del proceso de codificación de noticias en este entorno, con el fin de comparar los rendimientos de ambos con respecto al uso del recurso en 


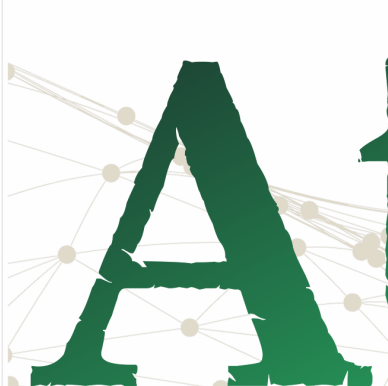

ISSN n² 2526-8031

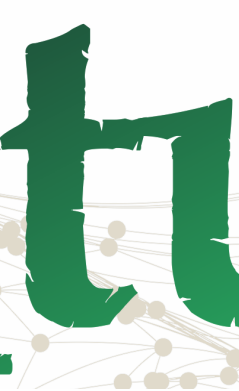

tur

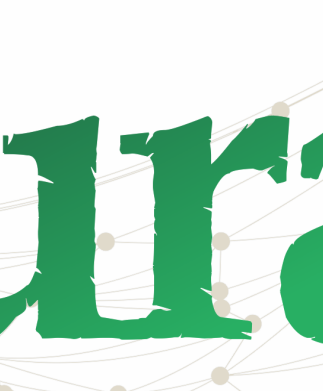

Vol. 3, n. 3, Setembro-Dezembro. 2019

cuestión, para reflexionar sobre las posibilidades del lenguaje periodístico en las Historias. Por lo tanto, la metodología adoptada fue la adopción del punto de vista semiótico para los estudios de comunicación, según Machado (2001).

PALABRAS CLAVE: Lengua Periodista; Instagram; Stories; Jornal O Globo; Portal A Crítica.

Recebido em: 19.06.2019. Aceito em: 09.08.2019. Publicado em: 01.09.2019. 


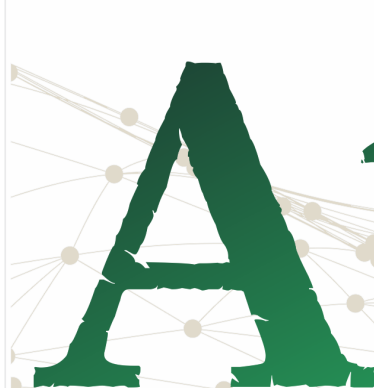

ISSN n² 2526-8031
Revista

Pan-Amazônica

de Comunicação

Vol. 3, n. 3, Setembro-Dezembro. 2019

\section{Introdução}

A existência de uma relação conectiva entre a linguagem inerente às Stories do Instagram e a linguagem jornalística é uma estrutura que ainda está em vias de se estabelecer. Atualmente, o tratamento da notícia neste espaço se resume a mera replicação dos conteúdos já publicados em outro site. Para que as potencialidades de linguagem das Stories do Instagram sejam mais bem aproveitadas é imprescindível que o jornalista se debruce sobre as possibilidades de construção da notícia neste ambiente, desde a produção até a sua distribuição pelas redes. Entender o jornalismo como alicerce das tomadas de decisões diárias da vida é o que motiva este artigo a abarcar questões relativas à linguagem da notícia nas Stories.

O modus operandi dos veículos jornalísticos em outros suportes - que não a internet - pode refletir no tratamento que a notícia recebe quando transposta para os sites de redes sociais e, em especial, às notícias publicadas nas Stories do Instagram. Inúmeros veículos e agências de notícia de diferentes segmentos e localidades possuem um perfil no Instagram. A plataforma, que hoje acumula cerca de 800 milhões de usuários em todo o mundo, propõe uma linguagem inteiramente visual e objetiva, razão pela qual veículos já consolidados, como Estadão, Folha de S. Paulo, Jornal O Globo e Nexo Jornal, viram no Instagram uma oportunidade para se aproximar cada vez mais de seu público e atraí-lo para suas publicações na internet.

O interesse desses veículos pela plataforma aumentou ainda mais quando o aplicativo lançou, em 2016, as Stories, que têm se mostrado cada vez mais importantes na distribuição da notícia na internet, já que mais de 300 milhões de contas usam as histórias do Instagram diariamente. No entanto, a adesão dos veículos a essa nova forma de interação está em fase embrionária, já que padrões jornalísticos de linguagem e estética ainda não estão completamente inseridos neste meio.

A concepção das Stories no Instagram partiu do sucesso que foi o Snapchat em seu auge, no ano de 2016. O aplicativo permite a captura de fotos e gravação de vídeos com o acréscimo de textos e desenhos à imagem, 


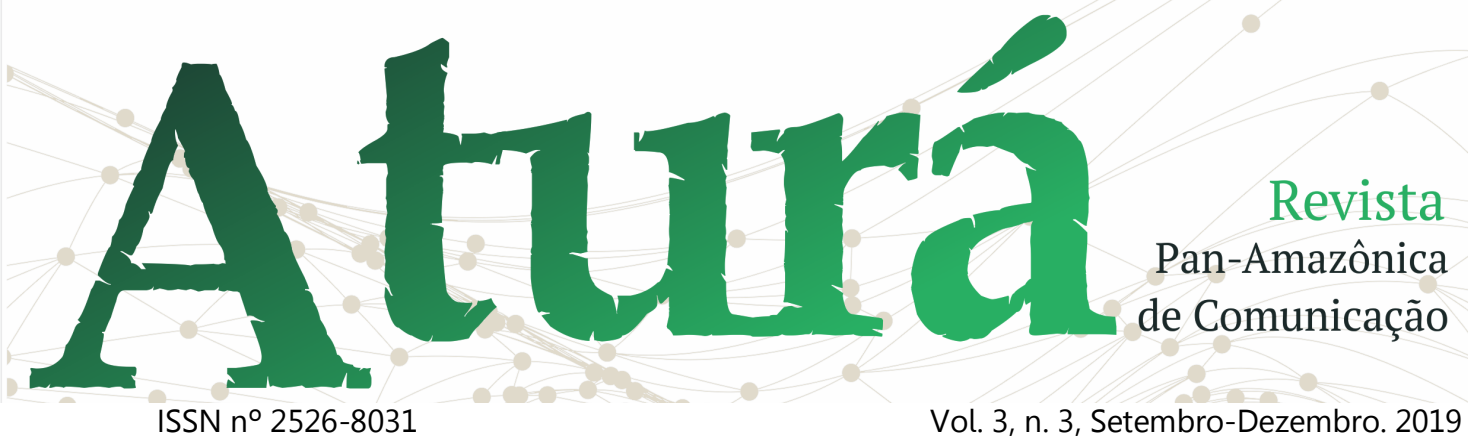

possibilitando que, antes de ser postado, o usuário escolha o tempo que a criação ficará no visor do amigo de sua lista. O tempo de cada "snap" é de 1 a 10 segundos e, após aberto, a imagem ou vídeo somente poderá ser vista pelo tempo escolhido pelo remetente. Em 24 horas, a imagem é excluída do dispositivo e também dos servidores. O aplicativo também permite adicionar filtros nas fotos, salvar as fotos tiradas no app no computador e anexar arquivos ao bate-papo dentro do Snapchat.

O Instagram lançou recursos similares em seu aplicativo, as chamadas "Stories" ("histórias", em português), cuja principal característica é dar aos usuários a possibilidade de criarem vídeos curtos, que desaparecem depois de 24 horas da sua publicação, com o intuito de permitir que os usuários compartilhem posts informais sobre as suas atividades diárias. Disponíveis desde agosto de 2016 no Instagram, as "histórias" podem ser em vídeo, foto, texto e conter emojis, adesivos, gifs e desenhos. As cenas são mostradas uma após a outra como se fossem uma exibição de slides, sendo possível avançar ou retroceder.

Diferentemente do Snapchat, as Stories do Instagram se caracterizam pela praticidade. Os recursos disponíveis estão todos na tela. Para acessar as stories basta entrar no aplicativo do Instagram, arrastar a tela para o lado (no feed) e começar a gravar - ou fotografar. A criatividade vem em seguida, quando o usuário opta por ornar sua imagem com textos, gifs e desenhos (FIGURA 01). 


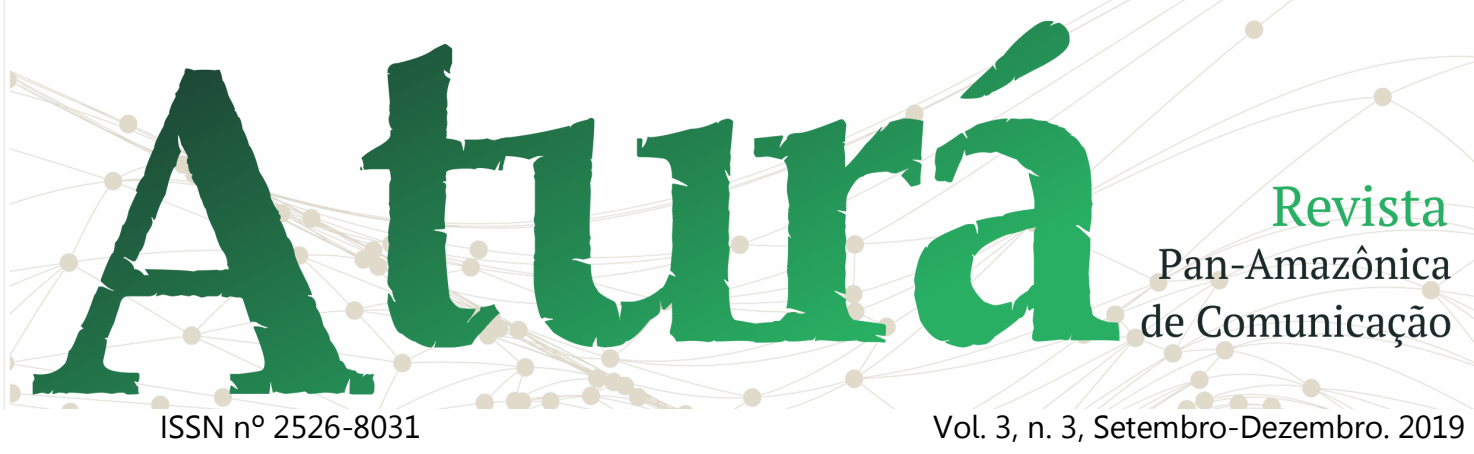

Figura 01 - Panorama da simplicidade das Stories do Instagram
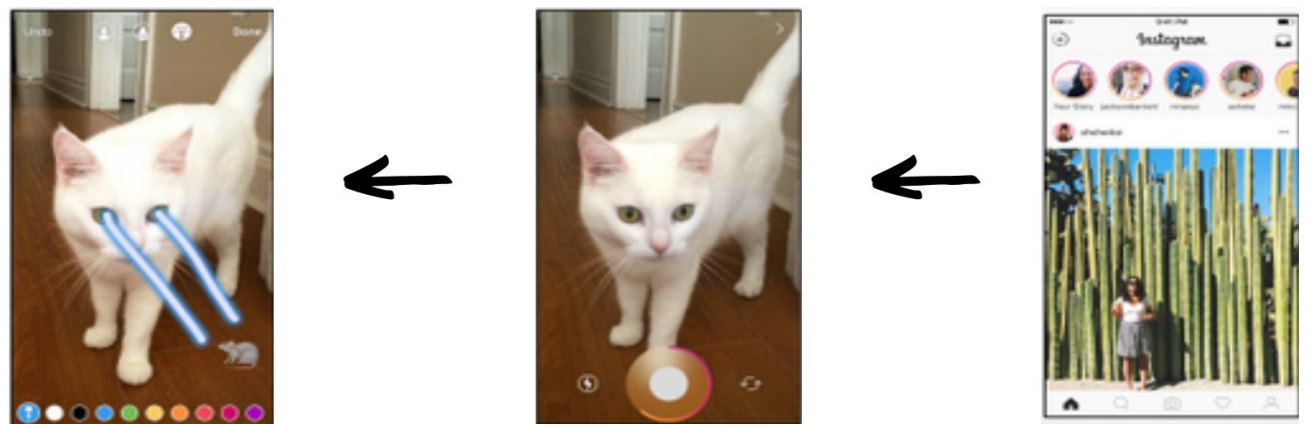

Fonte: Reprodução/Instagram (2019)

Nota: Mostra desde o modo de apresentação das Stories no perfil dos usuários seguidos até o template de produção da Story.

É perceptível uma simplificação do formato "Story" no template do Instagram, que amplia a experiência do usuário. A interface do Snapchat segmenta o conteúdo publicado pelos usuários; logo, conteúdos noticiosos, de caráter informativo podem ser facilmente encontrados na sessão "Discover", que é própria de notícias; além de uma ala de bate-papo e um leque de recursos para a produção das postagens.

Nas Stories a segmentação do conteúdo publicado não existe. Todos os usuários que utilizam as stories são exibidos num mesmo espaço, sem diferenciação entre o que é informação qualificada ou não. Portanto, enquanto o Snapchat é o aplicativo cujo direcionamento é a produção de conteúdo em formato story, as Stories do Instagram são uma parte, um recurso dentro do Instagram, que originalmente era voltado à publicação de imagens apenas no feed.

A disseminação da informação neste ambiente é tão primária que a forma de apropriação das Stories por cada veículo é diferente não só entre si como também nos arranjos que fazem à notícia. A cada momento, um estilo de cores e grafos, formato (em foto ou vídeo) e estratégia (roteirizado ou não) é usado, sem que haja um padrão. Amplas possibilidades surgem a partir deste recurso e infundam os veículos 


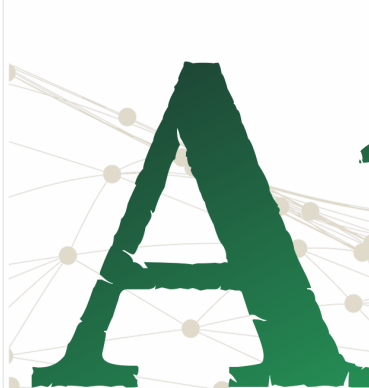

ISSN n² 2526-8031
Revista

Pan-Amazônica

de Comunicação

Vol. 3, n. 3, Setembro-Dezembro. 2019

jornalísticos de dúvidas sobre como fazer jornalismo neste espaço.

Alguns veículos, como o Estadão e a Folha de S. Paulo, migraram também para este meio e têm colocado as Stories entre as principais ferramentas de fonte de informação, tanto que a frequência de posts nesses perfis é diária. No entanto, a ausência de um padrão estético na inserção de imagens que ilustrem as informações divulgadas vai de encontro à proposta de leitura das próprias stories

Em contrapartida, a objetividade do Nexo Jornal é mantida também neste espaço, aliada a uma das suas principais características editoriais, o infojornalismo gênero jornalístico que utiliza recursos gráficos para apresentação sucinta e atraente da notícia - para informar através das Stories. Uma série de frames trazem dados e destaques a palavras-chave da notícia sobre determinado tema, mas com a permanência de um padrão na apresentação estética do conteúdo, com cores e fontes próprias do site.

Para qualificar a pesquisa e sistematizar o estudo, foram observados alguns elementos próprios das Stories que auxiliaram na fase de investigação do comportamento da linguagem jornalística neste ambiente dentro dos perfis do Jornal O Globo e do Portal A Crítica, que são colocados nesta pesquisa como objetos de estudo. E, apesar de diferentes entre si, essas características podem convergir para um padrão jornalístico que há de auxiliar na difusão da informação, de modo a torná-la atrativa para o público, com garantia de credibilidade e compromisso com o conteúdo disseminado.

Neste contexto de possibilidades de produção das stories do Instagram, o presente estudo propõe investigar de que modo o Portal A Crítica e o Jornal O Globo se apropriam desse ambiente na fase de produção e publicação de conteúdo jornalístico. Para isso, fez-se necessário identificar o processo de codificação da notícia no ambiente das Stories do Instagram, trazendo conceitos percebidos a partir da distribuição da notícia neste meio, para comparar as performances dos dois veículos jornalísticos na utilização do ambiente em questão e, finalmente, refletir 


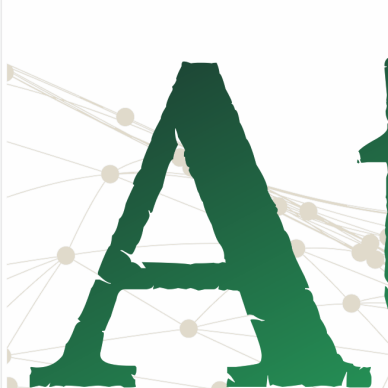

ISSN n² 2526-8031
Revista

Pan-Amazônica

de Comunicação

Vol. 3, n. 3, Setembro-Dezembro. 2019 sobre as possibilidades da linguagem jornalística nas Stories do Instagram. Nesse contexto, foram analisadas as estratégias de tratamento da notícia utilizadas nos perfis do Jornal O Globo e o Portal A Crítica dentro da ferramenta em questão, visto que ambos experimentam diferentes abordagens neste aspecto.

O Jornal O Globo desperta interesse por mostrar que se apropria das Stories de modo diferenciado; aparenta estar experimentando com o quadro semanal "Sextou", que se alia ao entretenimento. Em contrapartida, o Portal A Crítica, site oriundo da capital amazonense, está adaptando seu conteúdo na internet às potencialidades que o Instagram dispõe. Aparentemente, não arrisca tanto em experimentos inovadores quanto o Jornal O Globo, mas é o que melhor representa essa tentativa de padronizar o recurso e utilizá-lo como formato jornalístico na região Norte.

\section{Discorrendo Conceitos Sobre os Desafios do Jornalismo na Internet}

No Brasil, a internet começou a se popularizar a partir do ano 2000 e, de lá para cá, vem ganhando cada vez mais adeptos que, em sua maioria, são usuários ativos de redes sociais. De acordo com uma pesquisa realizada pelo Comitê Gestor da Internet no Brasil (CGI), em janeiro de 2019, a rede obteve um crescimento exponencial nos últimos anos. Em 2006, apenas 19\% das residências possuíam computadores e 14\% tinham acesso à Internet. Apenas onze anos depois, em 2017, 49\% das residências já possuíam computadores e $61 \%$ estavam conectadas à Internet. A mesma pesquisa revelou que, do total de usuários da Internet, 77\% são usuários de redes sociais. Ainda de acordo com os dados do CGI, o Brasil é o quarto país mais conectado do mundo, atrás, apenas dos EUA, Índia e China.

As transformações em curso no jornalismo têm lançado desafios e horizontes relacionados à pesquisa, à inovação e ao desenvolvimento tecnológico para todos os setores e agentes envolvidos com a atividade, inclusive a universidade, por esta ser responsável pela formação do jornalista e por sua capacidade de gerar pesquisa teórica. Daí surge a necessidade do jornalista contemplar as novidades virtuais 


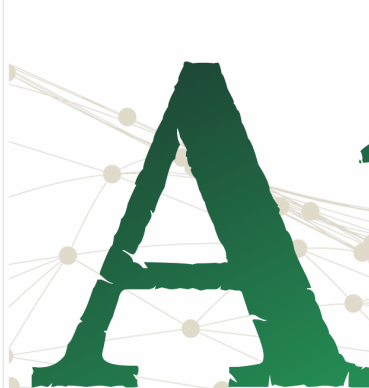

ISSN n² 2526-8031
Revista

Pan-Amazônica

de Comunicação que o cercam. A principal ferramenta deste profissional é, por sua vez, a mesma que caracteriza a internet e atrai usuários para os sites de rede social: a linguagem. Partindo disso, este artigo, apresenta resultados finais do estudo desenvolvido através de projeto de pesquisa pelo Programa Institucional de Bolsas de Iniciação Científica, financiado pela Fundação de Amparo à Pesquisa do Estado do Amazonas, sobre o comportamento da linguagem jornalística no ambiente das Stories do Instagram, bem como desvelamentos acerca do uso dos recursos disponíveis na plataforma durante o processo de codificação da notícia.

Outro ponto importante está relacionado às estratégias desenvolvidas pelos jornais para chamar a participação do público usuário/leitor. Essas ações configuram-se como um meio de o público criar vínculos com os veículos de comunicação, na medida em que eles deixam de ser receptores passivos e passam a fazer parte do processo de comunicação. O sociólogo francês Michel Maffesoli chama atenção para essa necessidade quando coloca que "as pessoas não querem só informação na mídia, mas também é fundamentalmente ver-se, ouvir- se, participar, contar o próprio cotidiano para si mesmas e para aqueles com quem convivem. A informação serve de cimento social". (MAFFESOLI, 2003, p. 25)

É observado que o jornalismo em plataformas digitais está construindo seu espaço com métodos, ainda, indefinidos. Não existe um padrão, um modelo pronto ou, como chamamos no cotidiano das redações, um manual jornalístico para as redes sociais; o processo de produção de conteúdo é, ainda, intuitivo. $E$, apesar de se tratar de uma ferramenta nova, as Stories contemplam números altos de usuários adeptos ao seu formato de visualizações, ultrapassando até mesmo o percussor da modalidade: a rede social efêmera Snapchat.

Para viabilizar o estudo dentro deste recurso e compreender a linguagem que os perfis utilizam para informar foi desenvolvido um estudo dos perfis do jornal O Globo e do Portal A Crítica, com o intuito de analisar quais características próprias das Stories estão sendo empregadas na construção desta linguagem. Ambos os 


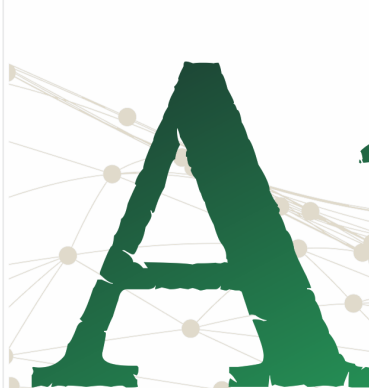

ISSN n² 2526-8031
Revista

Pan-Amazônica

de Comunicação

Vol. 3, n. 3, Setembro-Dezembro. 2019

veículos veem na plataforma um atalho para o engajamento do conteúdo que é publicado e distribuído na internet, além de estarem experimentando novos formatos dentro desse mecanismo, explorando a linguagem e tentando padronizar o recurso e utilizá-lo como formato jornalístico.

\section{Processo Metodológico de Análise das Stories}

Foram realizados (a) levantamento bibliográfico; (b) observação; e (c) análise dos dados. Posteriormente, quatro fases foram implementadas: 1. Pesquisa de referências e 2. Aplicação da ARS; 3. Organização e comparação dos dados coletados; e 4. Interpretação dos resultados.

Ao enfocar na linguagem jornalística, este artigo adota como método o ponto de vista semiótico para os estudos da comunicação (MACHADO, 2001, pp. 279 309). Isto implica focar nos processos do signo e da significação das mensagens da comunicação. Sob esta perspectiva, o objeto em questão torna-se a dinâmica da produção das linguagens da cultura e, ao mesmo tempo, as manifestações geradas pelos mecanismos semióticos da cultura de organizar informação em linguagens. Assim, o objeto de estudo enfoca a semiose, o princípio de auto geração dos signos que garante às mensagens, como sistemas organizados de signos que são uma dinâmica dialógica e inventiva na cultura. $\mathrm{Na}$ abordagem semiótica da comunicação, a semiose é o que permite focalizar as instâncias da comunicação como lugar de produção de mensagens, de transformação da informação em signo, de geração e circulação de sentido, de construção de campos de significação, de criação de circuitos de respondibilidade (MACHADO, 2001, p. 282).

Mensagem aqui não diz respeito apenas àquilo que sai de uma fonte e atinge um receptor graças à existência de um código previamente constituído; trata-se de um processo dinâmico de significação que implica tanto a operação conjunta entre fonte e recepção para codificar a informação, quanto a variedade de códigos que entram em ação no processo de recodificação. (MACHADO, 2001, p. 279)

$E$, compreendendo que a internet é esse espaço repleto de transmutação, faz-se necessário considerar que a linguagem uma 


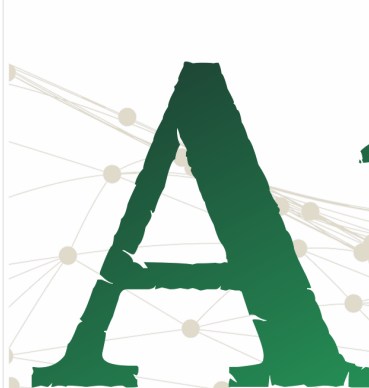

ISSN n² 2526-8031
Revista

Pan-Amazônica

de Comunicação

Vol. 3, n. 3, Setembro-Dezembro. 2019 vez constituída nas plataformas, pode, gradualmente, ser aprimorada, modificada e sofrer alterações. $\mathrm{O}$ ambiente é inconstante, mas o âmago do que o compõe, o mecanismo que o integra é, no mesmo passo, uniforme.

Para facilitar a compreensão do estudo e otimizar o tempo de pesquisa, foi definido um período de amostragem para a execução da (b) observação e da (c) análise dos dados coletados. Foi definido que as stories publicadas na segunda semana de Janeiro de 2019, do dia 18 de janeiro até 25 do mesmo mês, serviriam de parâmetro para a pesquisa. A partir daí, o (a) levantamento bibliográfico possibilitou que os próximos passos fossem executados.

Com o resultado das eleições e a titulação do atual presidente da república, Jair Bolsonaro, observamos que o conteúdo a emergir desses veículos de comunicação na plataforma em questão, nos daria o alicerce perfeito para estudar esse período de amostragem escolhido, que precede a primeira semana do ano - quando as formalidades pós-eleição são exercidas - e que, por conta disso, nos deu ainda mais tópicos para abordar na pesquisa.

$\mathrm{Na}$ segunda etapa foi realizada a codificação da notícia neste espaço, a partir do ponto de vista semiótico, posto por Machado (2001), que visa contemplar as abordagens de linguagem e estética nas Stories do Instagram.

Foram estabelecidos critérios para melhor avaliar a performance dos dois veículos nas Stories. a) a padronização da identidade, ou seja, qualificação do conteúdo como próprio de determinado veículo através de cores e princípios visuais; b) frequência de publicação, garantia de consumo de informação e conteúdo por parte dos seguidores diariamente e c) a linguagem usada nas stories, que deve representar a linha editorial do veículo, considerar a audiência que colabora com o engajamento das publicações e a credibilidade jornalística.

Os citados critérios foram observados durante o período de amostragem definido, que resultou na combinação de códigos característicos às stories e auxiliares na percepção do que vem a se tornar padrão 


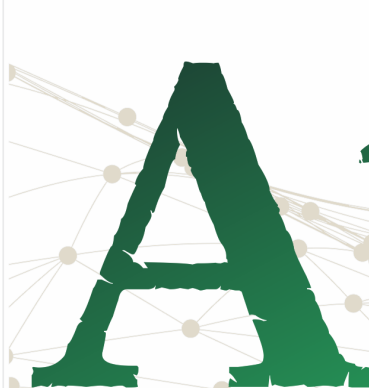

ISSN n 2526-8031
Revista

Pan-Amazônica

de Comunicação jornalístico, que contribuem para o tratamento e publicação do que se tem como notícia neste espaço, aqui propostos como verticalidade, sincronismo e complementaridade de frames - pílulas de story, que dentro de uma sequência podem tratar de um mesmo assunto ou transitar para outros.

Esses códigos se fazem presentes nas produções dos veículos estudados, mas ainda há uma quebra de cores, fontes e abordagens que não se aplicam a essas características durante a construção da notícia no ambiente deste recurso. Essa tríade, quando bem explorada, pode potencializar o fazer jornalístico nas Stories.

\section{Verticalidade}

No dicionário, o termo 'verticalidade' se refere à qualidade do que é vertical ou se encontra nessa posição. A definição pode não ser só atrelada ao que estrutura um frame de story, como também pode ser relativizada para o fato de que é uma característica que propõe um tipo de leitura visual. As stories do Instagram foram criadas com $O$ intuito de intensificar 0 compartilhamento do cotidiano da vida das pessoas para seus seguidores, já que por conta da grande adesão ao smartphone, a qualquer momento do dia, é possível gravar um vídeo ou fazer uma foto. Este fenômeno comunicacional, que deu aos usuários de rede social o poder de criar conteúdo sobre qualquer assunto através do celular, ocasionou o formato de exibição de vídeo em vertical.

Pensar em conteúdo para a internet implica em pensar nos enquadramentos precisos para as stories, pois é necessário entender que nem tudo que está no ambiente pronto para ser capturado vai estar contido na publicação final. Elementos de cenário, texto e foto devem ser centralizados e o espaço criteriosamente pensado para não excluir o âmago da informação que se quer passar.

\section{Sincronismo}

Após o entendimento da verticalidade, é importante ser colocado também uma outra característica própria às stories, aqui denominada como sincronismo, que neste 


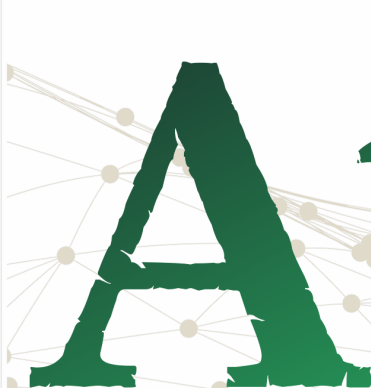

ISSN n² 2526-8031
Revista

Pan-Amazônica

de Comunicação

Vol. 3, n. 3, Setembro-Dezembro. 2019 ambiente denota a relação de tempo e leitura de um frame.

O tempo de leitura por story é prédefinido em 15 segundos, isso obriga o veículo jornalístico a ser sintético na publicação. É necessário que a notícia seja transmitida nesse curto espaço de tempo, mas não obstante, é indispensável a notoriedade do texto, do destaque. Entre os recursos disponibilizados neste ambiente, está o destaque de palavras, que pode agregar ainda mais à informação e ajudar na leitura síncrona que o seguidor faz da informação.

\section{Complementaridade de frames}

Para dar movimento e lógica ao assunto, as stories devem estar interrelacionadas, ou seja, a informação deve ser desmembrada em frames e fazer sentido na transição para o próximo. Essa interação entre story faz com que o leitor/usuário enfoque em cada parte da notícia. A ideia é simplificar a informação, torná-la atrativa e ágil. Vale ressaltar que a busca por informação neste ambiente está ligada à agilidade que o meio oferece.
Estes pontos foram categorizados e empregados na metodologia de análise do Jornal O Globo e do Portal A Crítica e serviram de parâmetro para o que vem sendo executado no ambiente das stories e mais bem detalhados ao longo desta pesquisa, através de análise semiótica das performances de ambos os veículos no que concerne à distribuição da notícia a partir da verticalidade, sincronismo e complementaridade de frames.

\section{Análise do Perfil do Portal A Crítica nas Stories do Instagram}

Em seu perfil no Instagram, o Portal A Crítica (@portalacritica) possui 143.012 seguidores - dado coletado em 04 de junho de 2019. Com uma frequência de dezenas de posts diários no feed, e uma média de 600 curtidas por foto, variando entre 140 até 2,4 mil likes, o tipo de interação dos usuários com as publicações depende do conteúdo. Em sua maioria, os posts trazem notícias factuais e atualidades em cultura e política.

O Portal A Crítica possui uma identidade visual padronizada, em cores e fontes e a linguagem mostra seriedade, 


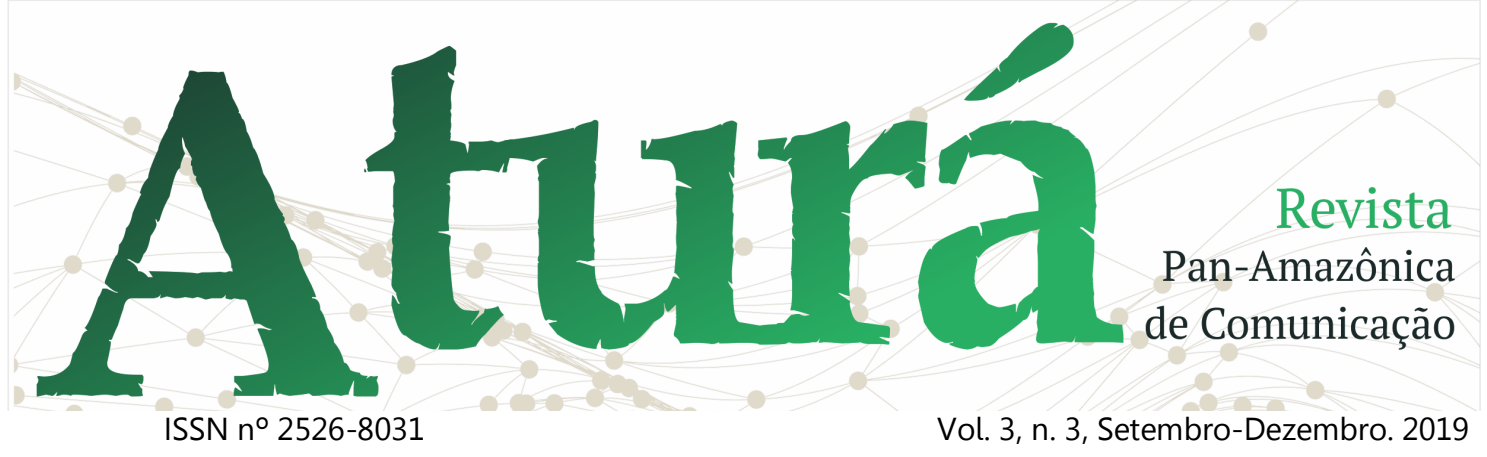

correspondendo ao lead da notícia. É mais sobre passar a informação de modo padrão e menos sobre se apropriar da linguagem da internet. O conteúdo publicado no feed do Instagram se configura pelo tratamento dado às legendas $e$ informações transmitidas, que são concisas.

Na bio (FIGURA 02), o perfil apresenta alguns canais para acompanhamento das

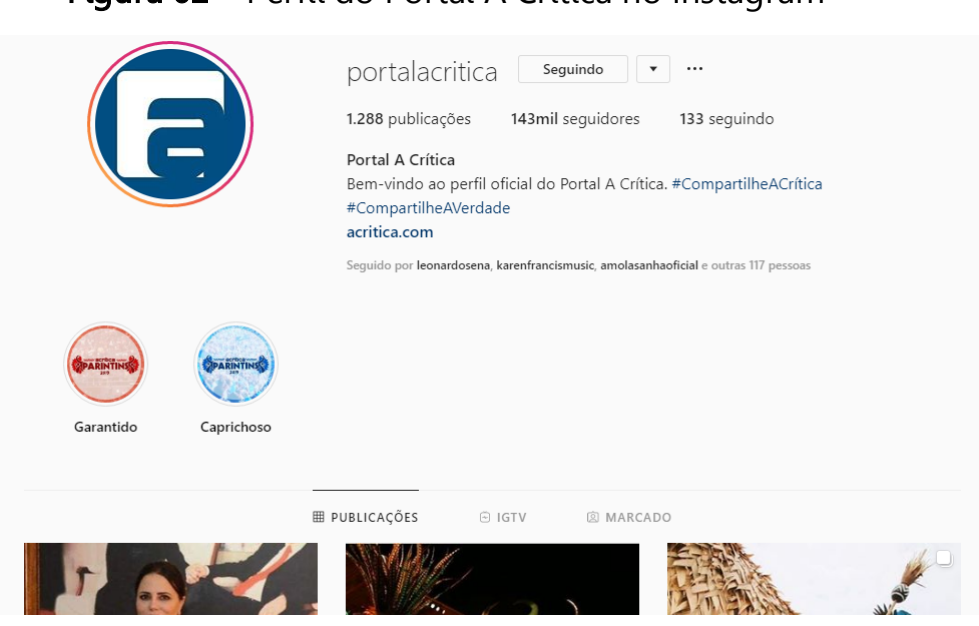

Fonte: Reprodução/Instagram Portal A Crítica (2019)

Nota: Mais de cem mil seguidores, com cumprimentos aos visitantes no perfil, hashtags próprias do veículo, informações e link para o portal. Vale destacar, ainda, a aderência das Stories como destaque na bio para a cobertura do evento anual no Amazonas, o Festival Cultural de Parintins.

No Portal A Crítica observou-se que as stories são elaboradas de acordo com as notícias factuais - entendo, aqui, por "factual" as hard news, notícias do dia, que têm validade de veiculação -, produzidas principais notícias do jornal, seguido do user do próprio veículo, uma hashtag e um link para o portal. Nos destaques, as stories são da cobertura do evento anual no Amazonas, o Festival Cultural de Parintins, o qual a emissora detém todos os direitos sobre. 


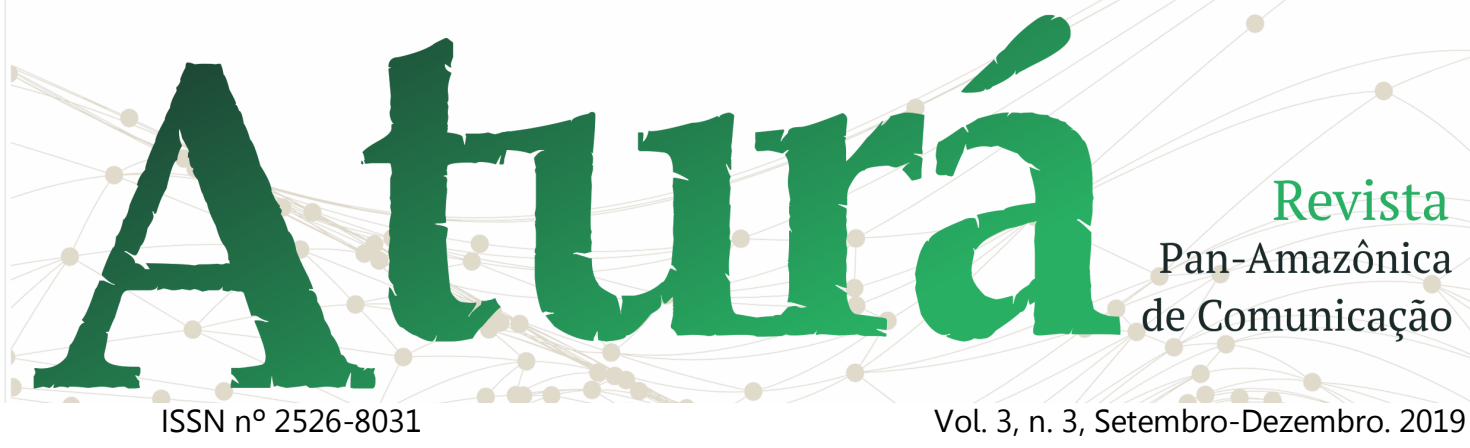

A impressão é de que o material é todo produzido dentro do próprio aplicativo através de um smartphone, sem uma maior preocupação estética de padronização do design das stories. Não há uma preocupação com a verticalidade que é orientada pela ferramenta; as imagens usadas para ilustrar as informações são, em suma, inseridas na horizontal. Essa ausência de cuidado com a linguagem visual das stories pode ser ocasionada justamente pelo fato de o perfil do veículo tender ao imediatismo, à velocidade da informação e à rotineira busca pelo furo jornalístico, o que acaba comprometendo a credibilidade da informação, conforme é observado na Figura 03, em que são dadas notícias factuais com recursos do próprio aplicativo, como o destaque por trás de todo o texto e a quebra de verticalidade em um frame e o destaque para a imagem toda em vertical no outro.

Figura 03 - Stories do Portal A Crítica sobre notícias factuais
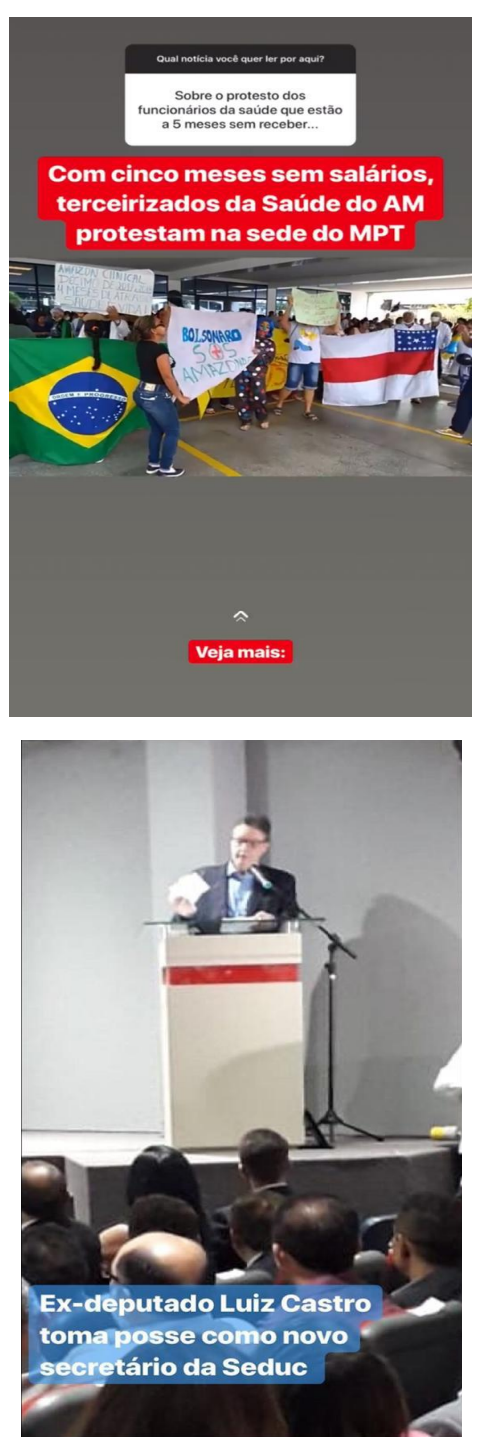

Fonte: Instagram Stories/Portal A Crítica

$(19 / 01 / 2019)$

Nota: Manifestação dos servidores terceirizados da Secretaria de Estado de Saúde do Amazonas; Cerimônia de posse do secretário da educação do Amazonas. Exemplos de produção de Story sobre notícias factuais. 


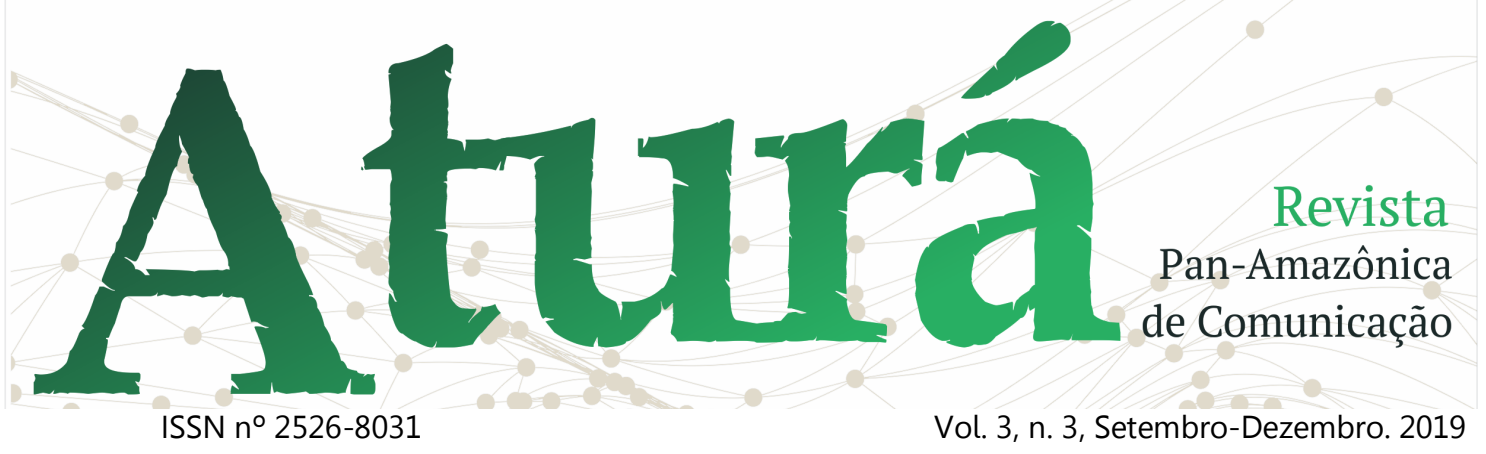

Neste sentido, avaliamos até então, que a forma de usar as Stories do Instagram pelo Portal A Crítica para noticiar, mostra que ainda existe uma certa timidez ao inovar em quadros e formatos de vídeo. É notável que não há padronização quanto aos formatos, já que a cada demanda de posts, o design e a proposta visual não cumprem um padrão. Logo, até mesmo a credibilidade jornalística é comprometida. A inserção de memes e gifs também é outro déficit na produção das Stories do Portal A Crítica. Os efeitos sociais ao veicular uma notícia devem ser levados em consideração.

Em um post (FIGURA 04) durante o período das eleições de 2018, referente à notícia de desistência do, até então précandidato Jair Bolsonaro, de participar dos debates, o Portal acrescentou um gif do candidato. De forma irônica e, até mesmo sarcástica, o gifimpõe uma certa adesão do Portal à candidatura de Bolsonaro. Este feito compromete a credibilidade do veículo. $\mathrm{O}$ mesmo aconteceu no segundo turno das eleições, porém com a inserção de um sticker aludindo a jogos de luta (FIGURA 04).

Figura 04 - Stories do Portal A Crítica nas eleições presidenciais de 2018
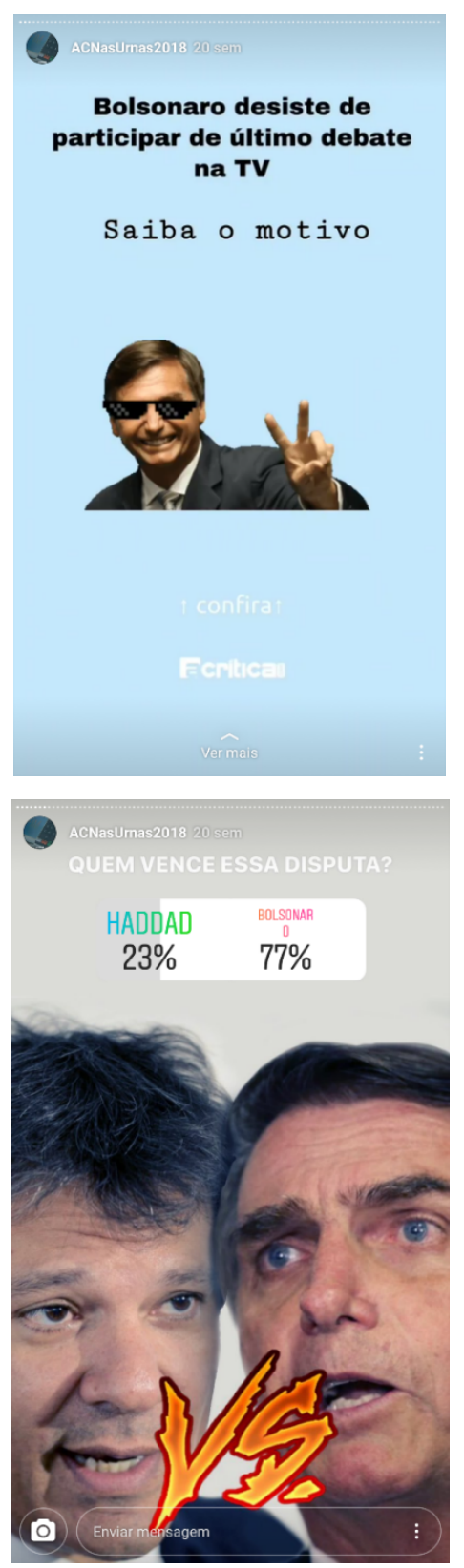

Fonte: Reprodução/Instagram Portal A Crítica (2018) 


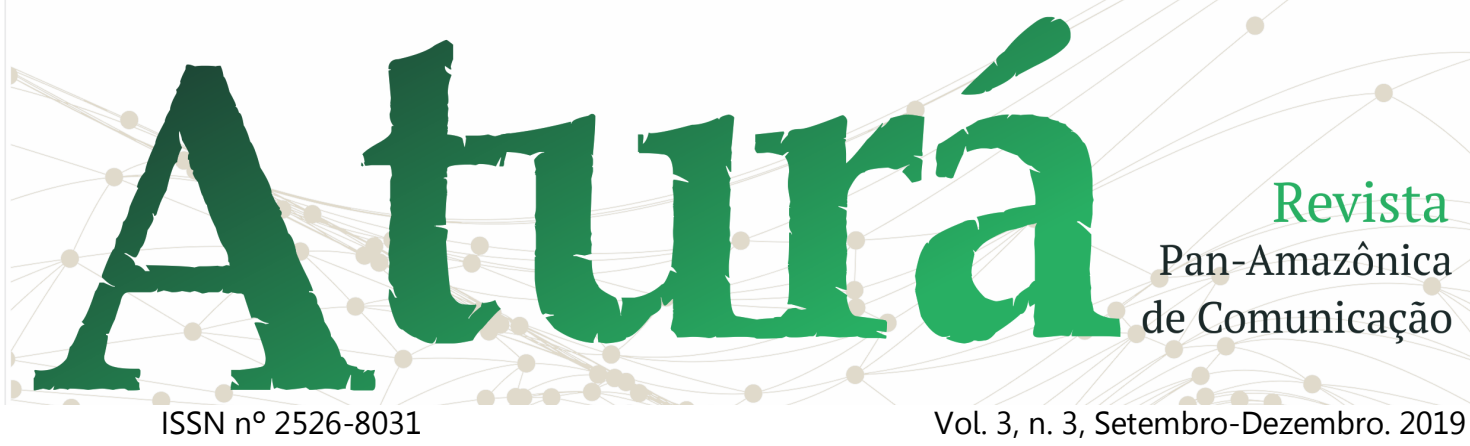

Nota: Gifs e adesivos são usados para qualificar as manchetes sobre a eleição (em 2018)

As stories do Portal A Crítica são, em suma, sobre assuntos factuais. Logo, o tratamento da notícia é igualmente instantâneo. Não há produção gráfica ou cuidado textual ao transpor o material publicado no site do portal para as Stories. O que pode haver, de acordo com o que foi analisado no período de amostragem, é uma preocupação em manter os seguidores - lêse público - por perto, opinando, sugerindo e fazendo parte da programação dentro das Stories. Essa estratégia, que também pode ser caracterizada como jornalismo colaborativo, é implementada quando uma caixa de diálogo é aberta em um frame de story, dando espaço para que o seguidor opine ou responda algo que pode ser questionado na caixa, conforme ilustra a Figura 05.

Figura 05 - Enquetes nas Stories do Portal A Crítica

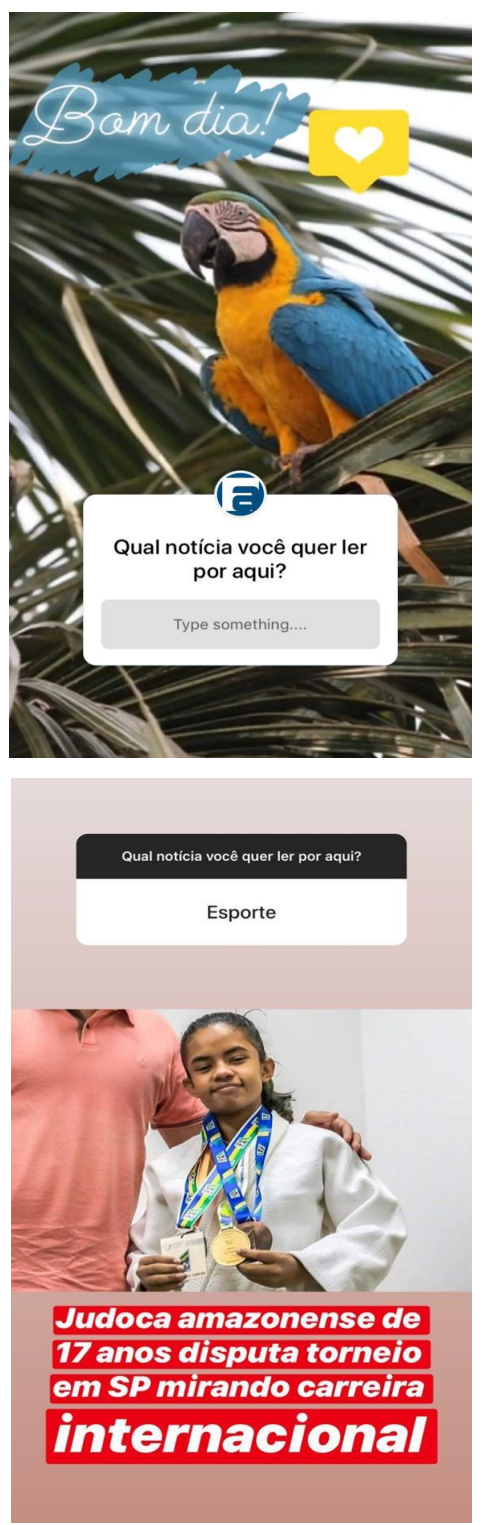

Fonte: Reprodução/Instagram Portal A Crítica (2019)

Nota: A partir de interação com seguidores, as notícias do dia vão sendo publicadas. 


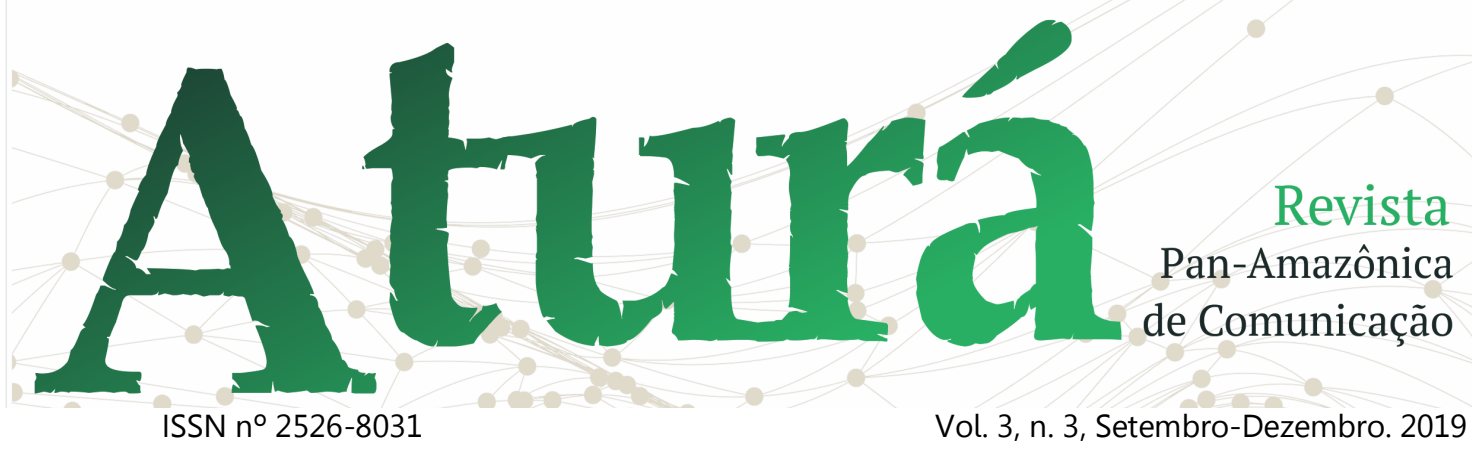

Este espaço de interatividade com o seguidor estabelece, automaticamente, um sincronismo em relação à leitura e ao tempo de story, pois o leitor que responde a perguntam se atém a notícia em questão e se sente parte do conteúdo a vir ser publicado posteriormente. $\mathrm{O}$ caso ilustrado pela Figura 06 mostra que, a partir da resposta de um seguidor cujo interesse é por esporte, uma notícia desta editoria foi transmitida. $E$, neste mesmo caso é implementada a complementaridade de frames, já que há uma continuidade de assunto.

\section{Análise do Perfil do Jornal $O$ Globo nas Stories do Instagram}

Em seu perfil no Instagram, O Jornal O Globo (@jornaloglobo) possui 1.443.330 seguidores - dado coletado em 04 de junho de 2019, conforme mostra a Figura 06. Com uma frequência de dezenas de posts diários no feed, e uma média de 2 mil curtidas por fotos, variando entre mil até 20 mil likes, o tipo de interação dos usuários com as publicações depende do conteúdo. Em sua maioria, os posts trazem curiosidades ou sínteses das principais notícias do dia.

Figura 06 - Perfil do Jornal O Globo no Instagram

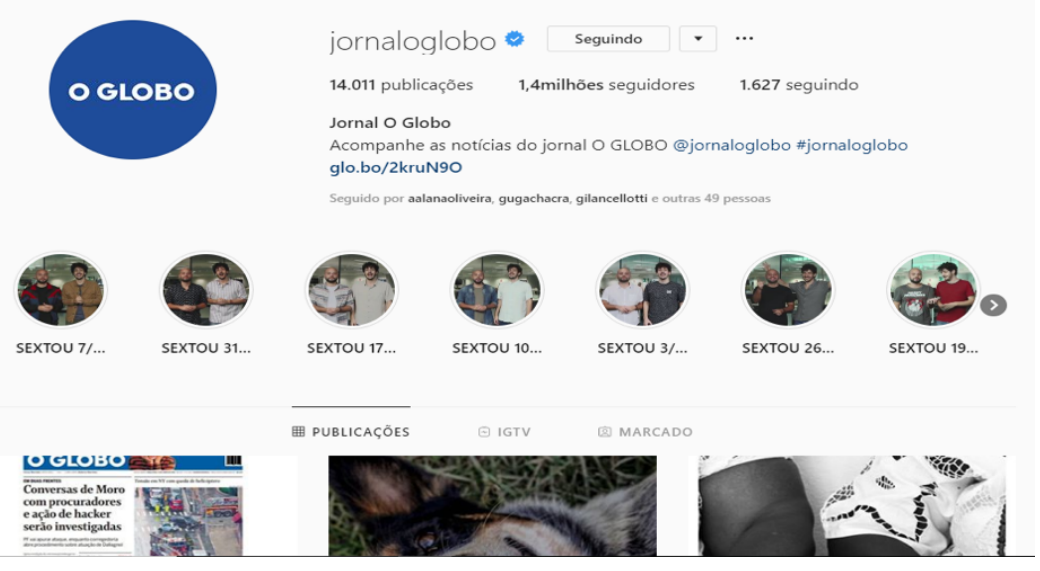

Fonte: Reprodução/Instagram Jornal O Globo

Nota: Com mais de um milhão de seguidores, informações de canais do veículo, links, hashtags e o próprio user do perfil. Vale destacar, ainda, a aderência das Stories como destaque na bio. 


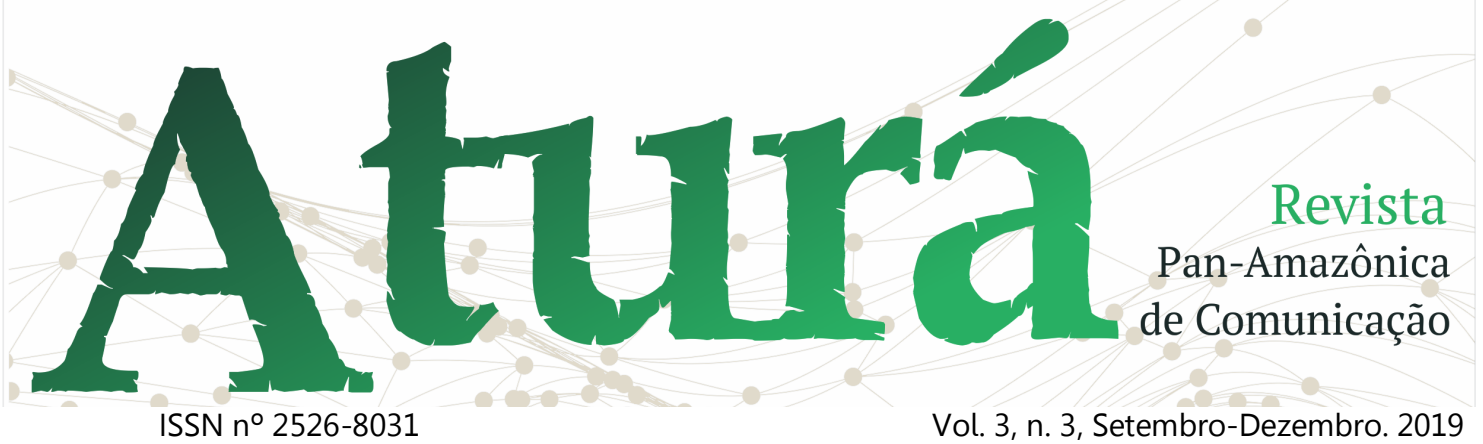

O Jornal O Globo possui uma identidade visual padronizada, em cores e fontes e, até mesmo, em linguagem. No conteúdo publicado no feeda abordagem é, em suma, informal, mas obedece a normalidade ortográfica da língua - o que caracteriza a credibilidade do jornal -, entendendo que no ambiente digital a compreensão da linguagem do ambiente é importante para ser entendido e creditado, além de obter engajamento orgânico.

$\mathrm{Na}$ bio o perfil apresenta alguns canais para acompanhamento das principais notícias do jornal, seguido do user do próprio veículo, uma hashtag e um link para

o site principal de notícias do jornal. Nos destaques, as Stories são do quadro roteirizado e apresentado pelos jornalistas Pedro Willmersdorf e Giovanni Sanfilippo, o 'Sextou'. Todas as edições do quadro estão em destaque.

Neste post (FIGURA 07) sobre a poluição das praias cariocas, a legenda traz um questionamento para o seguidor, provocando e estimulando-o a interagir com o veículo por meio dos comentários. Esta atitude assídua nas postagens traduz um comportamento similar - de interação - nas stories do Instagram.

Figura 07 - Post no perfil do Jornal O Globo
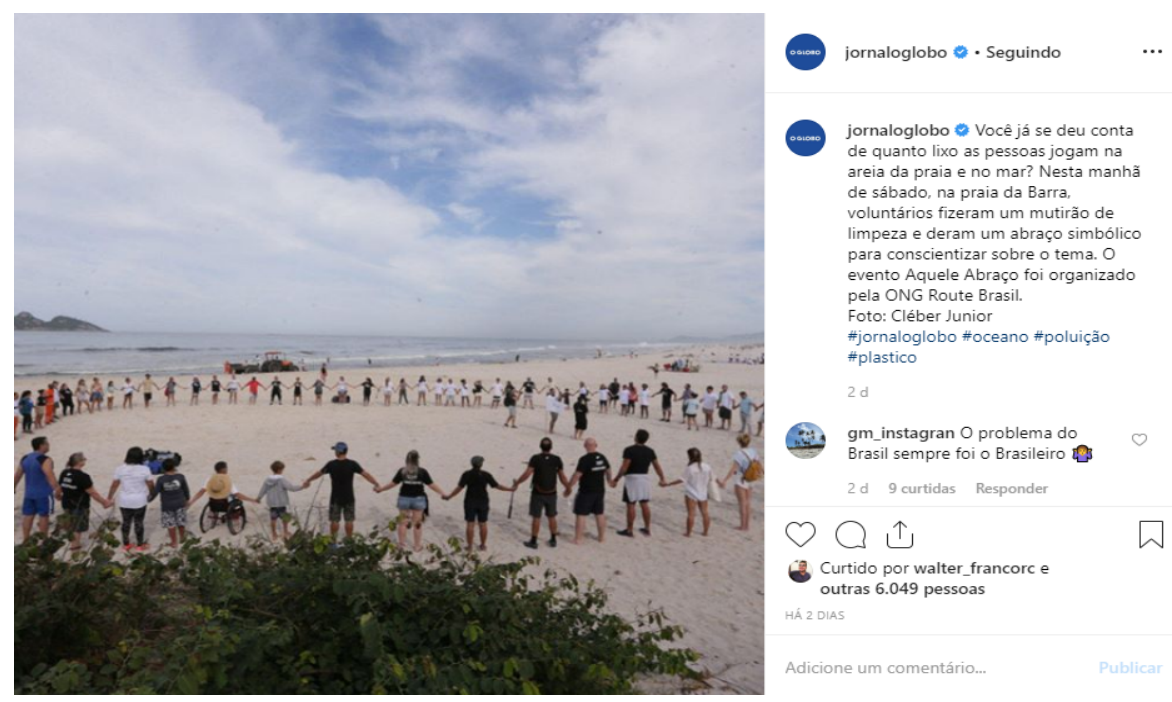

Fonte: Reprodução/Instagram Jornal O Globo 


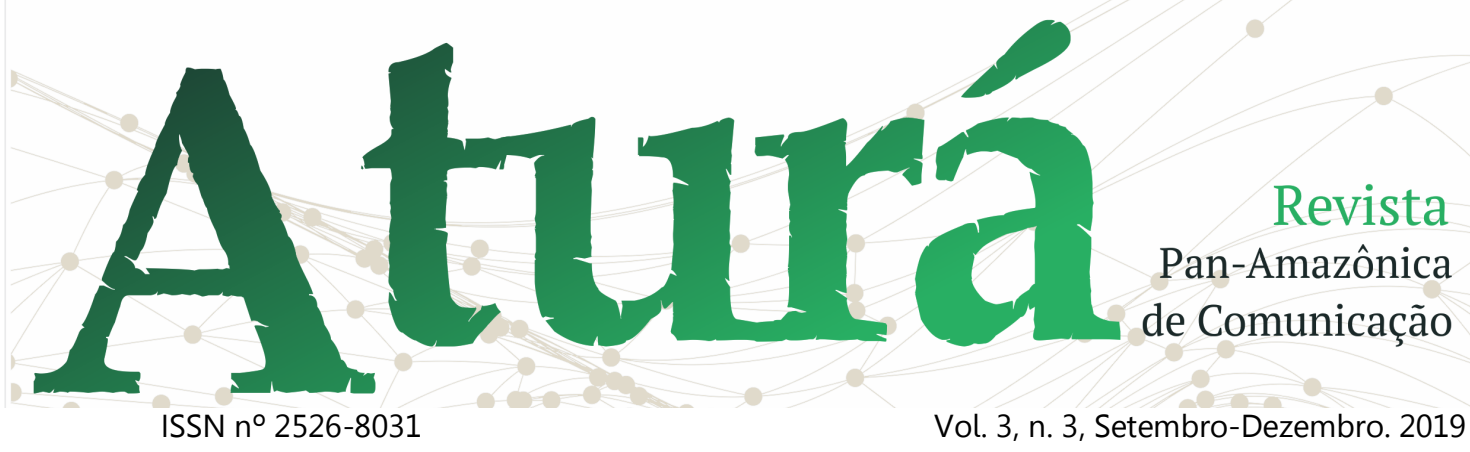

Nota: Poluição nas praias cariocas.

refere à verticalidade da tela. No entanto,

O Jornal $O$ Globo se atém às atualidades, não pendendo tanto para o imediatismo. A preocupação com a alimentação semanal da rede através da exibição de um quadro de giro de notícias nas Stories do Instagram que, basicamente, se trata de um resumo das notícias mais comentadas na semana. O diferencial está na linguagem empregada no texto dos jornalistas e na edição do material, que transparece determinado cuidado em gravar o vídeo na orientação vertical - o que demonstra certo entendimento da proposta da ferramenta - e de uma edição visual e sonora estruturada; feita fora do aplicativo.

O Jornal O Globo experimenta de diversas maneiras o recurso. Há de se observar, inclusive, que há uma retomada de costumes televisivos dentro das Stories. Isso acontece dentro de um quadro em que dois jornalistas resumem as principais notícias da semana. O quadro se dá com os jornalistas de pé, com fundo para a redação, em plano aberto. O formato é interessante por se alinhar com a proposta das Stories no que se enquanto narram também fazem piadas sobre as pautas. $O$ quadro recebeu o nome de "Sextou" (FIGURA 08), justamente por ser exibido toda sexta-feira e, como background, é tradição que haja umas batidas de funk.

Figura 08 - Abertura do quadro 'Sextou'

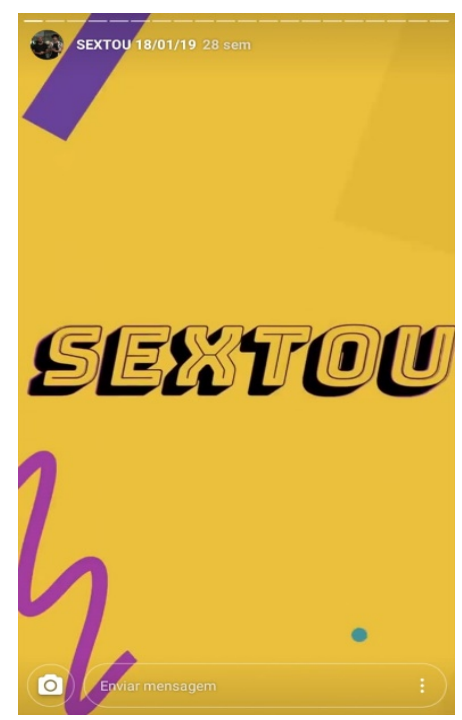

Fonte: Reprodução/Instagram Jornal O Globo (2019)

Nota: Ênfase para a logo e flash de abertura do quadro.

O quadro possui uma identidade visual própria com cores vibrantes e tons psicodélicos, o que garante o sincronismo entre stories, que apesar de não ser traduzido no desmembramento da notícia, 


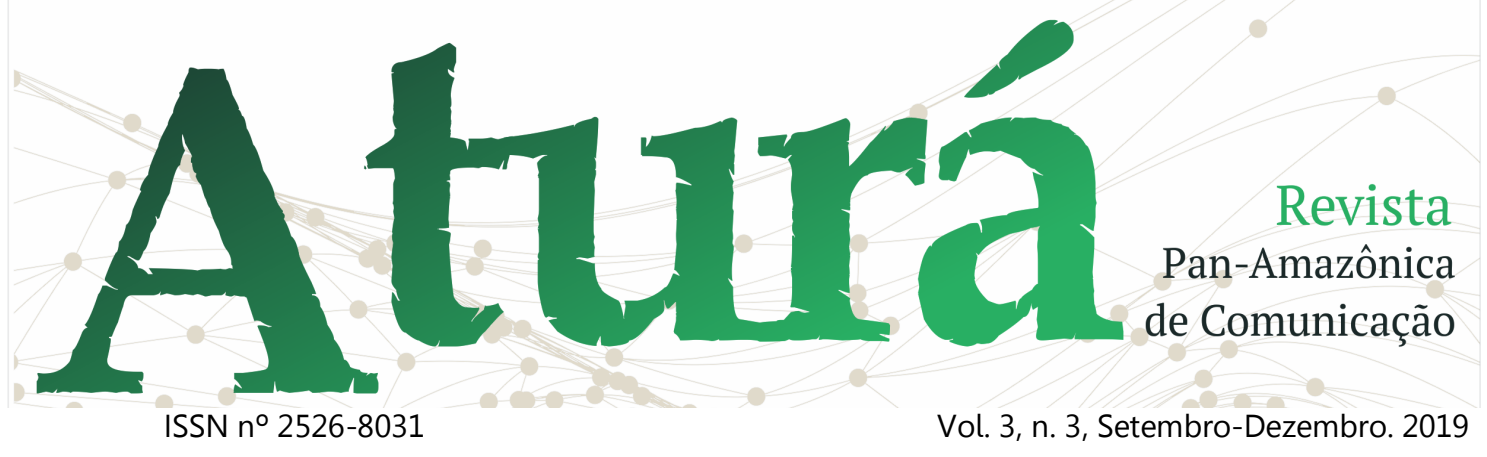

está na identidade visual do quadro, mantida ao longo de sua exibição, conforme é notado na Figura 08, que mostra a repetição de cores dos elementos gráficos presentes nos dois frames.

Outra singularidade do quadro é a complementaridade entre frames. $\mathrm{O}$ roteiro é todo voltado para um diálogo entre os dois jornalistas, de modo que as notícias sejam dadas espontaneamente, através de uma interação entre ambos. Isso mostra uma preocupação em cultivar elementos da linguagem da internet no roteiro; ou seja, ainda que esta ideia da permanência de um quadro semanal possa ser compreendida como oriunda da televisão, o que o torna feito na e para a internet é a linguagem; entende-se linguagem aqui, não só como a fala, o discurso verbalizado, mas a construção dele, o contexto, as expressões, o cenário e o direcionamento.

Até mesmo a vestimenta dos apresentadores demonstra descontração, leveza. Apesar de assuntos sérios, o conteúdo é passado de forma didática e, certamente, fixa no subconsciente de quem o assiste, por conta da linguagem memética e das expressões corporais exageradas, que pode ser melhor observado na Figura 10, quando os jornalistas brincam com uma notícia sobre política.

Figura 09 - Exibição do quadro 'Sextou'
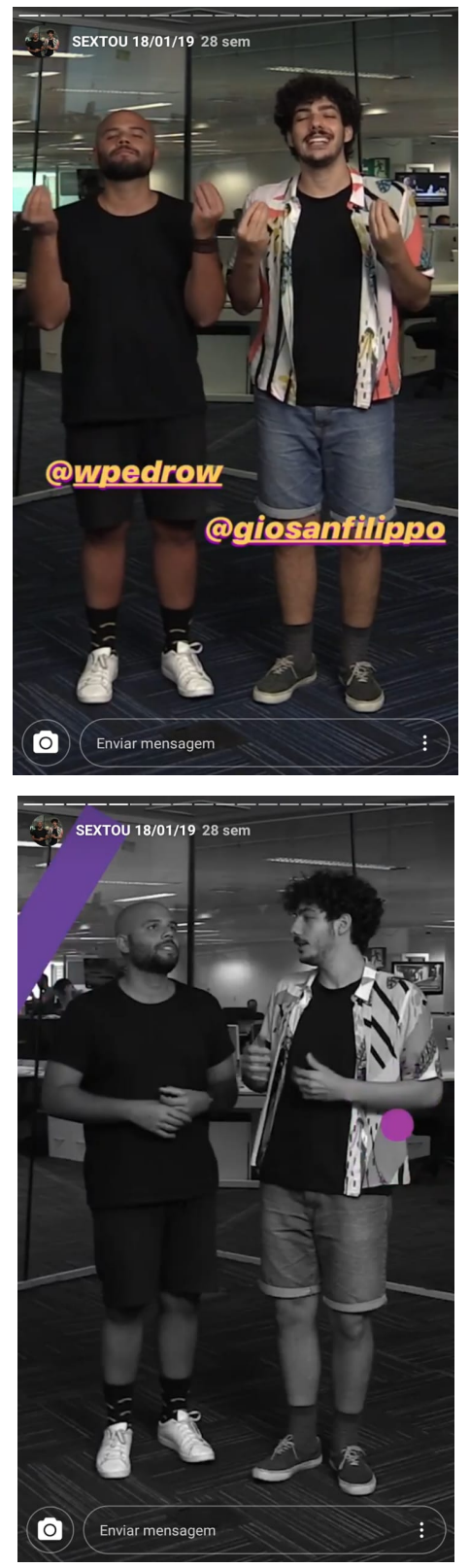


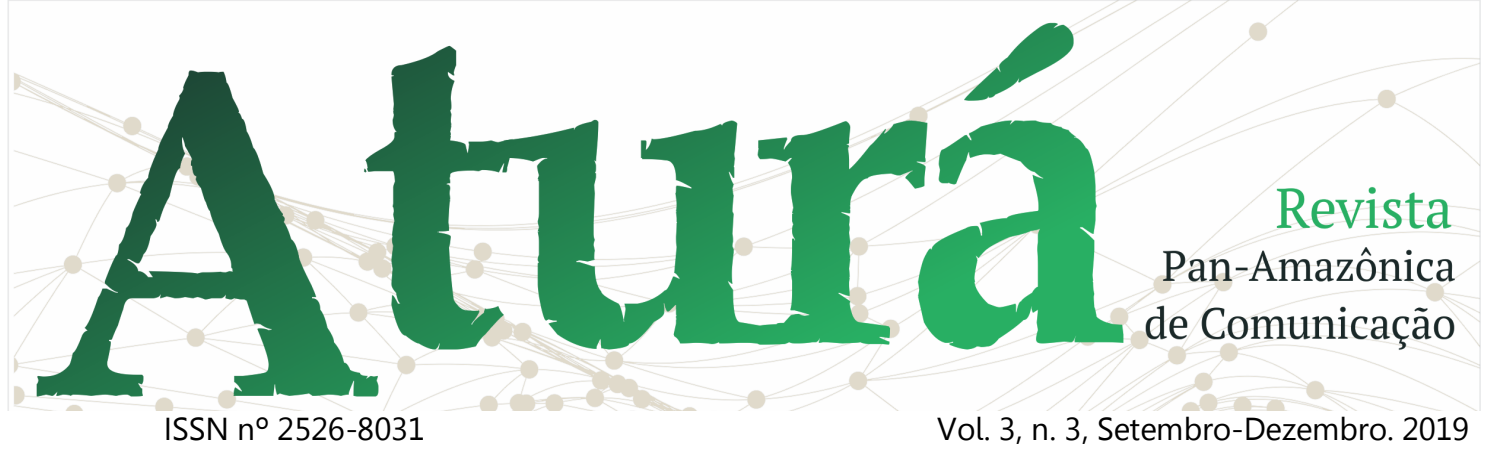

Fonte: Instagram Stories/Jornal O Globo

$(18 / 01 / 2019)$

Nota: Momento em que os apresentadores do quadro ironizam uma fala do atual presidente, parafraseando-o em italiano, com "la mamma è finita", por isso a gesticulação exagerada das mãos.

Outra característica é a identificação dos apresentadores (FIGURA 09) através de seus perfis (users) no Instagram. A inserção das arrobas (@wpedrow e @giosanfilippo) representa um hiperlink dentro do próprio site - uma característica própria da internet, que possibilita que o seguidor trafegue na própria plataforma e constate que os criadores de conteúdo do 'Sextou' estão aptos a prosseguir com o quadro, já que eles estão imersos na mesma plataforma que os seguidores do jornal e por conhecerem o site.

Existe uma relação de proximidade entre quem acompanha o perfil do jornal e as pessoas que criam conteúdo para o perfil do jornal. A internet, de fato, derrubou mais um paradigma que já foi, em um dado momento, o sucesso da televisão: a relação de passividade entre o telespectador e o jornalista, em que só um deles fala e o outro apenas observa.

Nesta story ilustrada na Figura 10, os apresentadores usam de um meme para explicar um acontecimento político nacional importantíssimo. Eles falam sobre a prisão do italiano Cesare Battisti que, à época, chegou à Itália depois de ser preso na Bolívia. A decisão surpreendeu o governo Bolsonaro que queria ter uma participação mais efetiva na prisão do Battisti, o que não aconteceu já que ele foi enviado direto para seu país de origem. Ao explicar a situação, o Pedro [um dos apresentadores; geralmente fica do lado esquerdo do vídeo], responde, usando o meme "sem tempo irmão" como uma justificativa para a não vinda do preso até o Brasil (FIGURA 10).

Figura 10- 'Sextou': destaque para o meme "sem tempo irmão" na tela 


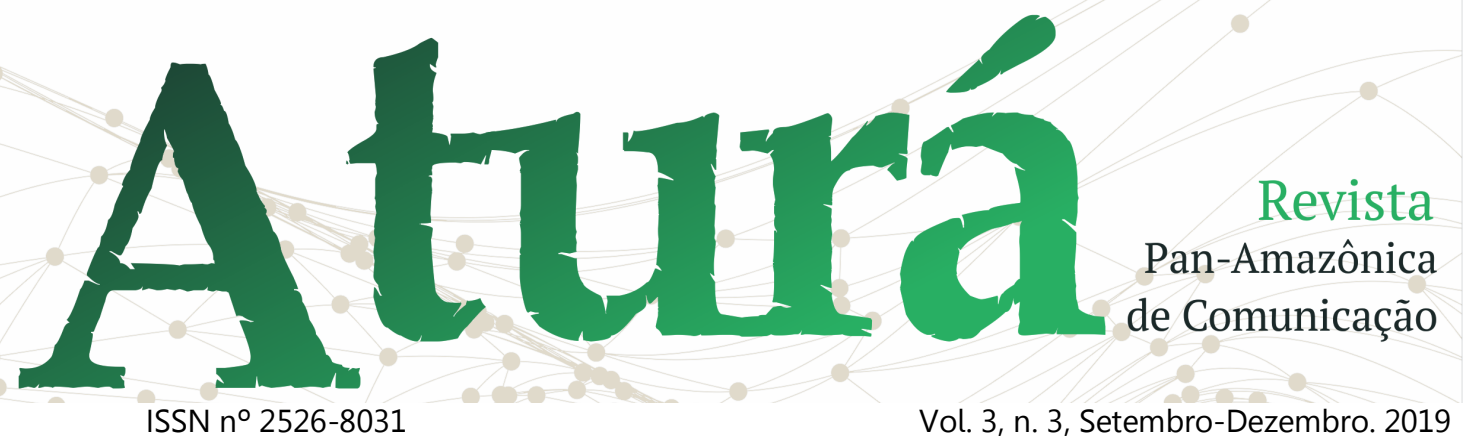

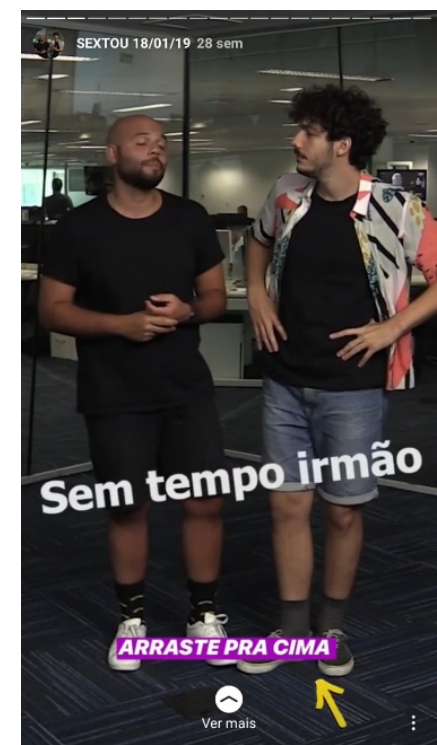

Fonte: Reprodução/Instagram Jornal O Globo (2019)

Nota: Jornalistas comentando o caso do italiano Bastitti.

A inserção de memes, paradas dramáticas e uso de filtros em preto e branco são características próprias do quadro. Essa tentativa de aliar a linguagem despojada que já está consolidada nas redes sociais às notícias da semana, mostra que o jornalismo pode ser didático e construtivo
Vol. 3, n. 3, Setembro-Dezembro. 2019 no ambiente online. No "Sextou", a criticidade do jornalismo ainda vigora e acompanha a linguagem proposta pelo quadro (de comicidade), pelas stories (de complementaridade) e pelo Instagram (de informalidade).

\section{Interpretação dos Resultados}

Ao longo do estudo foram apresentados três elementos característicos às Stories do Instagram: 1. Sincronismo; 2. A verticalidade $\mathrm{e} ; 3$. Complementaridade de frames. No entanto, o comportamento da linguagem da notícia no ambiente das Stories nos remete também a outros tantos elementos, que compõem de certo modo esta percepção do que é notícia neste espaço e o modo como é transmitida. Para fácil visualização e entendimento, organizamos, detalhamos e analisamos estes elementos na Tabela 01, que pode ser observada a seguir.

Tabela 01 - Códigos da linguagem jornalística nas Stories do Instagram

\begin{tabular}{|c|c|c|}
\hline Códigos & $\begin{array}{c}\text { Jornal O Globo } \\
\text { (@jornaloglobo) }\end{array}$ & $\begin{array}{c}\text { Portal A Crítica } \\
\text { (@portalacritica) }\end{array}$ \\
\hline $\begin{array}{c}\text { Tratamento da } \\
\text { notícia }\end{array}$ & $\begin{array}{c}\text { Compromisso com tratamento prévio } \\
\text { da notícia }\end{array}$ & $\begin{array}{c}\text { Replicação da notícia, com raro tratamento da } \\
\text { informação; participação do seguidor durante este } \\
\text { processo }\end{array}$ \\
\hline
\end{tabular}




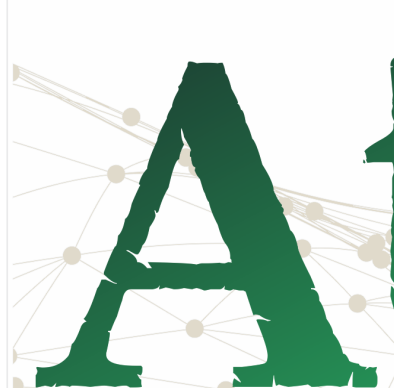

ISSN n² 2526-8031

\section{Revista}

Pan-Amazônica

de Comunicação

Vol. 3, n. 3, Setembro-Dezembro. 2019

\begin{tabular}{|c|c|c|}
\hline Verticalidade & $\begin{array}{l}\text { Aproveitamento da proposta, com } \\
\text { produção de conteúdo elaborado de } \\
\text { acordo com este recurso }\end{array}$ & $\begin{array}{l}\text { Entendimento da proposta, mas pouco uso dela; } \\
\text { com publicação de imagens na horizontal, } \\
\text { ocasionando uma quebra }\end{array}$ \\
\hline Sincronismo & $\begin{array}{l}\text { Roteiros elaborados com textos } \\
\text { diretos }\end{array}$ & $\begin{array}{c}\text { Chamadas rápidas para a notícia, através de } \\
\text { manchetes }\end{array}$ \\
\hline Experimentalismo & Ousadia na criação de conteúdo & Timidez ao inovar \\
\hline $\begin{array}{l}\text { Complementaridade } \\
\text { de frames }\end{array}$ & $\begin{array}{l}\text { Adoção de linguagem despojada, } \\
\text { repleta de referências; didatismo } \\
\text { reforçado com o uso da linguagem } \\
\text { memética própria da internet }\end{array}$ & Inserção de memes e gifs de forma desenfreada \\
\hline Humor & $\begin{array}{l}\text { Ironia comedida nos textos; humor é } \\
\text { uma característica forte }\end{array}$ & $\begin{array}{l}\text { Pende para o infotenimento e tende a exagerar na } \\
\text { dose do humor }\end{array}$ \\
\hline Padronização visual & Cores e fontes bem definidas & $\begin{array}{c}\text { Cores e fontes diferentes em cada publicação; a } \\
\text { logomarca do portal aparece esporadicamente como } \\
\text { marca d'água }\end{array}$ \\
\hline
\end{tabular}

Fonte: As autoras (2019)

Nota: comparação da performance dos dois veículos nas Stories do Instagram a partir de elementos inerentes ao recurso.

No tratamento da notícia é considerado de que forma o conteúdo é publicado nas Stories, se a notícia já pulicada em outros meios é replicada com o mesmo título sem muitas alterações, como ocorre no caso do Portal A Crítica, que se atém ao factual. O Jornal O Globo, no entanto, traz uma outra proposta de tratamento da notícia neste ambiente, pois há uma adaptação do texto da notícia quando transpassado para este ambiente.

A verticalidade é, na internet, uma característica própria às Stories; trata-se de adaptar a visão do usuário à leitura vertical dos frames, portanto, quando há uma quebra nesse sentido, como fotos na horizontal, a produção causa um estranhamento.

O sincronismo se relaciona com o tempo, pois há, neste ambiente, uma 


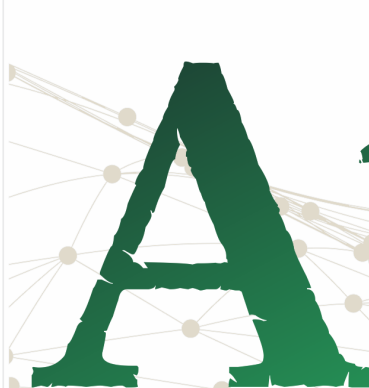

ISSN n² 2526-8031

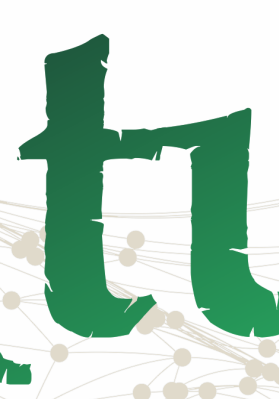

(t)

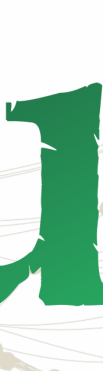

11

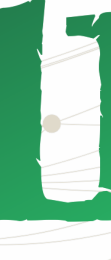

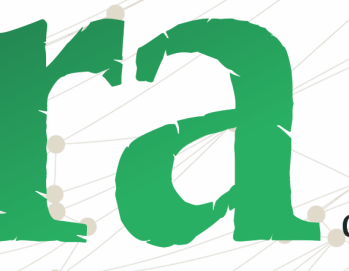

Vol. 3, n. 3, Setembro-Dezembro. 2019 necessidade de se fazer entender com apenas 15 segundos de frame e, ao mesmo tempo, tornar o conteúdo didático, atrativo, através do texto; transcrições na tela, por exemplo, podem trazer curiosidades que o jornalista não inclui na sua fala.

Experimentalismo está relacionado com a inovação de conteúdo próprio às Stories. O Jornal $\mathrm{O}$ Globo propõe semanalmente um quadro de giro de notícias todo formatado para este ambiente. Até então, nenhum outro veículo havia proposto tal feito.

A complementaridade de frames é sobre essa preocupação em relacionar a story seguinte com o anterior, de modo que haja alternância e dinamismo entre eles. $\mathrm{O}$ conteúdo pode, ao passar de cada toque na tela, ir complementando-se.

O humor já uma característica das redes sociais como um todo. Para se fazer entender neste ambiente, os veículos tiveram que enquadrar suas performances jornalísticas a este tipo de linguagem, repleta de conotações e gírias.

O uso de cores e fontes próprias à identidade visual do veículo jornalístico podem contribuir de forma considerável na distribuição de seu conteúdo, uma vez que as stories são inteiramente visuais e aproveitar esta peculiaridade para promoção da marca e criação de um padrão, visualmente falando.

\section{Conclusão}

Através deste estudo, foi possível observar as dinâmicas da comunicação jornalística nas Stories do Instagram. Compreender que este ambiente cobra uma adaptação à sua linguagem e um know how prévio das comunicações que ocorrem ali é o que potencializa a construção de pontes para aproximação junto ao público - ou "seguidores", no Instagram. Mas, ainda que a Story seja um recurso disposto em uma rede social, seu valor informativo não deve ser descartado.

As pessoas acompanham os portais de notícia, jornais, sites e blogs no Instagram com o objetivo único de se manter informado e, por conta disso, a qualidade da informação não deve decair com a justificativa de estar em um espaço sintético, 


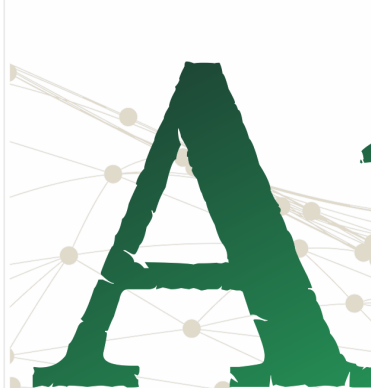

ISSN n² 2526-8031
Revista

Pan-Amazônica

de Comunicação

Vol. 3, n. 3, Setembro-Dezembro. 2019

que induz à objetividade, clareza, despojamento e que distrai.

É compreensível que o humor e a ironia sejam ingredientes presentes na comunicação online, mas é necessário certo cuidado para não cair na armadilha do que alguns autores relativizam como "infotenimento", que designa uma mistura de notícia com diversão. É uma "tendência a veicular, a qualquer preço, informações atraentes" (NEVEU, 2006, p.19). O uso desenfreado de gifs e stickers junto da manchete principal distribuída na Story pode alterar o real sentido da informação e comprometer a recepção da notícia.

É de suma importância que os veículos de comunicação aproveitem os recursos disponibilizados pela internet para fazer notícia. No entanto, ao se apropriar deste meio, é interessante que sejam impostos critérios ao distribuir a notícia. A linguagem das redes sociais deve ser um fator preponderante na hora de distribuir conteúdo, no entanto, elas devem ser adaptadas para a garantia - e permanência - da credibilidade.
A notícia deve ser transmitida de forma séria, creditável, com fins de mobilizar a população para tomadas de decisão, e não, apenas, para entreter. Considerando que a internet é esse espaço com potenciais a serem explorados, este estudo traçou um pontapé inicial para o que vem a ser as futuras discussões acerca do fazer jornalismo na internet, que não devem se limitar apenas às Stories do Instagram, mas ao ambiente digital como um todo, já que as dinâmicas da internet são intermitentes e trazem, em cada contexto, um modelo novo. Inicialmente, a problemática que norteou esta pesquisa foi a de traçar um norte para os veículos de comunicação compreenderem que a internet tem, sim, competência e potencialidades a serem exploradas, mas foi atestado ao longo do caminho que a essência do fazer jornalístico, a consciência ética sobre este ofício e a responsabilidade social estão em alta e perecem sobre todos e quaisquer recursos digitais. O diferencial não está tão somente no que é novidade, mas também no que embasa o processo. 


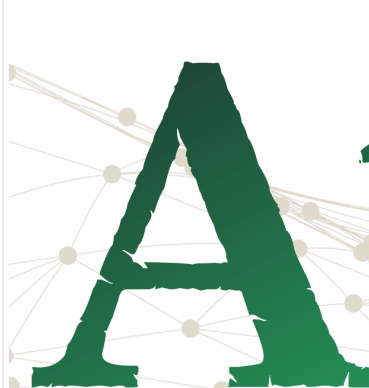

ISSN n² 2526-8031

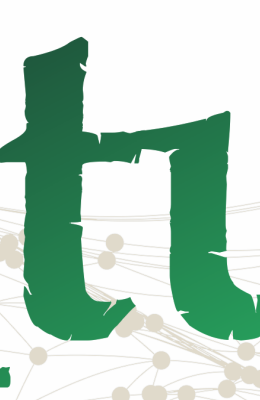

(1) ira

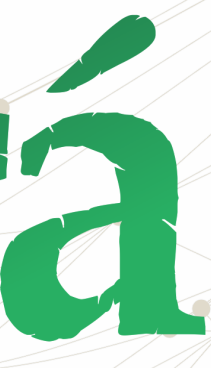

Vol. 3, n. 3, Setembro-Dezembro. 2019
Deste modo, este estudo desvelou questões importantes para as próximas pesquisas acerca da temática das Stories, trouxe elementos e analisou referências no assunto. O que o Portal A Crítica e o Jornal O Globo nos trazem é essa ideia de que há a necessidade de pensar o novo, de refletir para encontrar meios. Mas, para encontrar meios, a experimentação antecede e a criatividade vigora, de modo que o jornalista observe o que está sendo proposto para, então, apropriar-se.

\section{Referências}

BOTELHO, Jéssica. PEREIRA, Mirna Feitoza. Novas práticas e processos em ensino de jornalismo: A inovação do laboratório experimental de jornalismo em rede da Universidade Federal do Amazonas.. Revista Estudos de Jornalismo. Número 6, Volume 1 (Ensino, práticas e experiências no Jornalismo), 2016a. pp 36-52.

BOTELHO, J. T. S.. Inovação e ensino de jornalismo em rede na Amazônia: o LabF5. Trabalho de Conclusão de Curso. Curso de Jornalismo. Universidade Federal do
Amazonas. Manaus, 2016b. Oreintadora: Mirna Feitoza Pereira.

BOTELHO, Jéssica. PEREIRA, Mirna Feitoza. Laboratório de Experimentação em Jornalismo Digital da Ufam - Lab F5: ferramentas e procedimentos de produção, publicação e distribuição. Campo Grande MS: SBPJor - Associação Brasileira de Pesquisadores em Jornalismo, $V$ Encontro Nacional de Jovens Pesquisadores em Jornalismo, 2015a.

CERVO, A. L.; SILVA, R.; BERVIAN, P. A.

Metodologia científica. 6. ed. São Paulo:

Prentice. Hall do Brasil, 2006

CGI. Pesquisa sobre o uso das tecnologias de informação e comunicação no Brasil [livro eletrônico]: TIC Domićlios e Empresas 2012. Coordenação executiva e editorial Alexandre F. Barbosa. São Paulo: Comitê Gestor da Internet no Brasil, 2013.

MAFFESOLI, Michel. O instante eterno: o retorno do trágico nas sociedades pósmodernas. São Paulo: Zouk, 2003. 


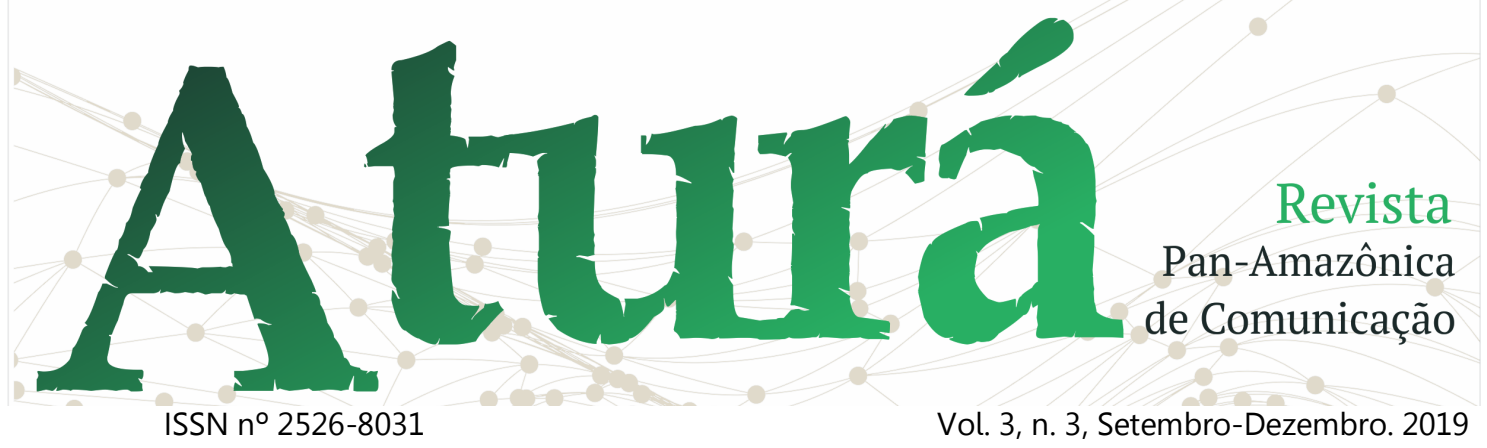

MACHADO, Irene. O ponto de vista semiótico. Teorias da comunicação: conceitos, escolas e tendências, v. 3, p. 279automatizados para 0 processo de produção industrial do jornalismo digital In: ANAIS XIV COMPÓS. Niterói/Rio de Janeiro, jun. 2005a.

309, 2001.

NEVEU, E. Sociologia do jornalismo. São Paulo: Loyola, 2006.

RECUERO, Raquel. Introdução à análise de redes sociais. Salvador: EDUFBA, 2017.

SCHWINGEL, Carla. Ferramentas de publicação de conteúdos na Internet no contexto do ciberjornalismo. In: CD ROM do XI Encontro de Professores de Jornalismo. São Paulo, 2008.

\section{Ciberjornalismo/Carla}

Schwingel. - São Paulo: Paulinas, 2012. (Coleção comunicação em pauta). . Comunicação e criação na Internet: análise das equipes de desenvolvimento Web e dos grupos de desenvolvimento de software. [Dissertação de Mestrado da Universidade Federal da Bahia], 2002. . Jornalismo digital de quarta geração: a emergência de sistemas 